
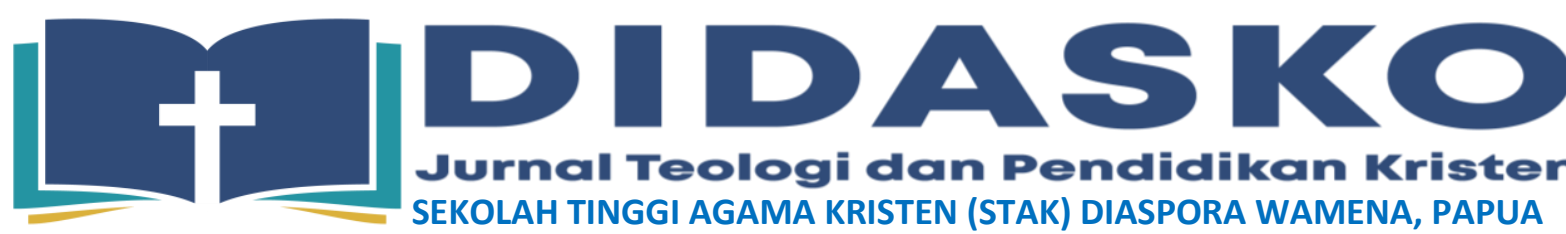

Jurnal Teologi dan Pendidikan Kristen SEKOLAH TINGGI AGAMA KRISTEN (STAK) DIASPORA WAMENA, PAPUA

Volume 1 Nomor 1 (April 2021)

Web STAK DIASPORA Wamena: http://stakdiaspora.ac.id

Web DIDASKO: http://e-journal.stakdiaspora.ac.id/index.php/didasko/index

\title{
EFISIENSI KEPEMIMPINAN GEMBALA SIDANG BAGI PERTUMBUHAN GEREJA
}

\author{
Semuel Rudy Angkouw ${ }^{1}$ \\ Sekolah Tinggi Alkitab Batu \\ Email: semuelangkouw@stabatu.ac.id \\ Simon $^{2}$ \\ Sekolah Tinggi Teologi Anugrah Indonesia \\ Email: simonpetrus45144@gmail.com
}

\begin{abstract}
This paper describes the efficiency of field-response leadership for church growth. The method used in the writing of this article is a qualitative method with a literature. The main idea was topic because it was found that there were shepherds who did not carry out their leadership duties as an efficient return. The impact on the growth of the church is minimal because there is no quantity increase. The growth of the church is due to being encouraged to be rewarded efficiently in shepherding the church. From the aspect of the reciprocal field manager, it can empower quickly, measurably and structurally what time, energy, and money has.
\end{abstract}

Keywords: Efficiency, Pastor, Church Growth

\begin{abstract}
ABSTRAK
Tulisan ini memaparkan tentang efisiensi kepemimpinan gembala sidang bagi pertumbuhan gereja. Metode yang digunakan dalam penulisan artikel ini adalah metode kualitatif dengan pendekatan kepustakaan. Gagasan pokok lahirnya topik ini karena ditemukan fakta, adanya gembala-gembala yang tidak melakukan tugas kepemimpinanya sebagai gembala secara efisien. Dampaknya pertumbuhan gereja minim karena tidak tercipta pertambahan secara kuantitas. Pertumbuhan gereja terjadi karena didorong bila gembala efisien dalam menggembalakan jemaat. K-efisien kepempinan gembala sidang dapat dilakukan dengan memberdayakan memberdayakan secara tepat, terukur, dan terstruktur apa yang dimiliki baik waktu, tenaga, uang.
\end{abstract}

Kata-kunci: Efisiensi, Gembala, Pertumbuhan Gereja 


\section{PENDAHULUAN}

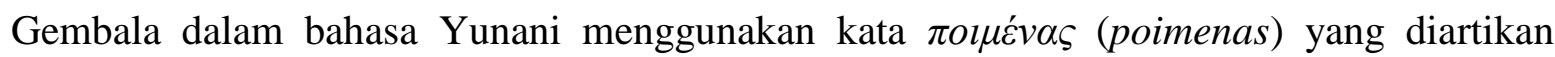
seorang pemberi makan, pelindung dan penuntun. Tetapi oleh Masweli sebutan gembala di masa kini adalah seseorang yang memimpin jemaat, mengarahkan kerohaniannya. Karena itu gembala sidang merupakan orang yang istimewa, jika ia dikaruniakan dan terpanggil untuk pelayanan dengan tujuan memelihara umat-Nya (Crider, 2002, p. 38). Gelar gembala yang ada dalam gereja memang sering dipakai dibanding dengan gelar lain. Gelar uskup (bishop), presbiter, pengkhotbah, imam, rohaniwan, dan sebagainya, walaupun telah lama digunakan tetapi dalam perkembangan sejarah gereja, gelar-gelar tersebut mengalami penerapan-penerapan yang tidak pada tempatnya, sehingga mengakibatkan gelar-gelar tersebut menjadi kabur artinya dan tidak lagi sesuai dengan arti yang sebenarnya. Sampai sejauh ini gelar gembala masih dapat diterima dalam setiap gereja tanpa menimbulkan pertentangan pengertian maupun penggunaan istilah tersebut. Ini merupakan persetujuan bersama bahwa seorang gembala diberi tanggung jawab selaku penggembala atas kawanan orang percaya umat Allah. Borrong mengemukakan pekerjaan sebagai pendeta merupakan kelanjutan dari pekerjaan orang-orang terpanggil secara khusus menjadi wakil dan mitra Allah dalam memberitakan firman-Nya di dunia ini. Karena itu pendeta adalah orang-orang terpanggil seperti imam, nabi, raja, dan rasul, khususnya gembala, untuk menjalankan tugas dan fungsi selaku pemberita kehendak dan maksud Tuhan kepada umat manusia di masa kini (Borrong, 2015, pp. 7980).

Gembala, penatua dan penilik jemaat merupakan tiga istilah yang menunjuk pada satu jabatan dalam Perjanjian Baru. Dalam Kisah Para Rasul 20:17,28, dikatakan bahwa para penatua gereja di Efesus telah dijadikan penilik atas kawanan, dengan tujuan agar mereka memberi makan atau menggembalakan jemaat di Efesus. Di sini kita menemukan istilah penatua, penilik jemaat dan gembala dipakai untuk menunjuk orang-orang yang sama(Henry C Thiessen, 2010) ${ }^{\circ}$ Gembala jemaat merupakan suatu jabatan di dalam gereja Tuhan yang diberikan oleh Kristus untuk mengurus sidang jemaat sebagai domba-dombaNya. Hal serupa dijelaskan oleh Nehemia Mimery bahwa sidang jemaat adalah kumpulan orang-orang yang sudah percaya dalam nama Yesus Kristus. Mereka dipanggil sebagai domba-domba milik Kristus. Penggembalaan domba-domba ini Kristus serahkan dan percayakan dalam tangan seorang gembala (Nehemia Mimery, n.d.).

Potret peran gembala yang berperan besar dalam penataan urusan pelayanan gerejawi terlihat jelas bila menyelidiki kitab Perjanjian Baru. Besarnya peran para gembala seperti Timotius, para Penatua di Efesus dan lainnya mendorong mereka untuk se-efektif dan se-efisien melakukan tugas penggembalaanya sebagai seorang pemimpin jemaat. Kehidupan hamba Tuhan dengan keluarganya, ia dapat secara tidak langsung memberikan contoh kepada sekitarnya yaitu bagaimana sesungguhnya kehidupan keluarga hamba Tuhan yang baik dan harmonis dan yang berkenan kepada Allah (Simon, 2019). Ini terlihat melalui himbauan rasul Paulus kepada Timotius dan para penatua di Efesus, agar memimpin atau menggembalakan jemaat dengan mencontoh apa yang sudah dilakukan oleh Paulus. Bagaimana dengan potret efisiensi kepemimpinan gembala sidang di masa kini dalam menggembalakan jemaat? Sebagai seorang gembala sidang yang sudah puluhan tahun dan masih menjadi gembala saat ini, ide dasar topik ini dibahas oleh penulis karena melihat, bertemu, adanya sebagian pendeta-pendeta yang tidak efisien dalam kepemimpinnya menggembalakan jemaat. Bila kepemimpinan gembala sidang tidak efisien, akan sulit mencapai pertumbuhan gereja. Padahal salah satu dari indikator dari pertumbuhan gereja adalah bertambahnya jemaat secara kuantitas. Budijanto mengemukakan ada empat aspek dari pertumbuhan gereja yang diukur, yaitu pertambahan jumlah jemaat, perintisan gereja baru, pertumbuhan kualitas iman dan melihat proses pertumbuhan gereja itu (Handi Irawan \& Bambang Budijanto, 2020, pp. 1-42).

Contoh dari tidak efisiensinya kepemimpinan gembala sidang yang penulis lihat dalam menggembalakan jemaat ialah, sering meninggalkan tempat penggembalaan akibatnya berkurang 
dedikasi dalam melayani jemaat dan pengembangan gereja lokal. Akibatnya gereja yang digembalakan terjadi stagnan padahal jika ditinjau dari segi waktu dalam menggembalakan sudah lama. Karena tak kunjung terjadi pertumbuhan gereja menjadi orang yang berpasrah diri bahkan seakan itu merupakan ketetapan Tuhan. Membangun argumentatif alasan dibalik tidak terciptanya pertumbuhan gereja merupakan bentuk perlindungan diri. Bila Allah telah memilih dan memberi kepercayaan panggilan gembala kepada seseorang dalam pelayanan, sebaiknya ia bertekun dalam penggembalaan agar berumbuh dan berkembang gereja lokal tersebut (Simon Simon, 2020).

Dengan melihat latar-belakang di atas, ruang lingkup yang akan diuraikan dalam penjabaran tulisan ini adalah bagaimana efisiensi kepemimpinan gembala sidang? Kemudian tentang pertumbuhan gereja diuraikan dalam tulisan ini. Dengan menguraikan tulisan ini, ada kontribusi teoritis dan praksisnya diperoleh pembaca. Bentuk kontribusi teoritisnya, melalui pemaparan tulisan ini dijelaskan bagaimana seharusnya menjadi gembala sidang yang efisien berdasarkan prinsip firman Allah dalam pertumbuhan gereja. Sedangkan praksisinya, tulisan ini menjadi sumbangsih untuk diterapkan dalam pelayanan pastoral oleh gembala.

\section{METODE PENELITIAN}

Menurut Mulyana metode adalah proses, prinsip dan prosedur yang digunakan untuk suatu pendekatan dalam mengkaji topik penelitian hingga mencari jawaban (Dedy Mulyana, 2002, p. 120). Metode yang peneliti gunakan dalam tulisan ini adalah metode kualitatif dengan pendekatan kepustakaan. Zed mengemukakan pendekataan kepustakaan untuk menjawab pertanyaan penelitian, sebab penelitian tersebut hanya dapat dijawab melalui penelitian kepustakaan karena data penelitian yang diperoleh berasal dari sumber perpustakaan (Zed, 2008, p. 2). Selain itu buku, jurnal dan wawancara digunakan dalam memperoleh data. Wawancara pada penulisan ini sifatnya wawancara tidak langsung dengan menggunakan sarana telepon dan whatsapp.

\section{PEMBAHASAN}

\section{Tugas Gembala}

Seorang gembala dipanggil dan ditetapkan oleh Tuhan bukan hanya untuk berkhotbah saja, melainkan yang terutama adalah menggembalakan jemaat sebagai kawanan domba. Gembala sebagai pemimpin harus mengajar firman Tuhan kepada jemaat, harus melatih setiap anggota jemaat untuk melakukan pelayanan-pelayanan holistik. Harus mampu menyaksikan kasih Kristus kepada setiap orang dan ini peran utama bagi seorang pemimpin (Kosta \& Djadi, 2011, p. 175). Hal senada dikemukakan oleh Cohall peran pendeta telah berkembang jauh melampaui dan tidak hanya sebatas penataan rohani jemaat. Jemaat mengharapkan pendeta dapat memenuhi peran kepemimpinan yang kompleks, layaknya sebagaimana pemimpin di lembaga sekuler, seperti administrator gereja, ahli strategi politik, dan aktivis sosial (Cohall \& Cooper, 2010). Rasul Paulus mengatakan kepada penatua-penatua jemaat di kota Efesus agar menjaga diri dan menjaga seluruh kawanan, karena kamulah yang telah ditetapkan Roh Kudus menjadi penilik untuk mengembalakan jemaat Allah yang diperolehNya dengan darah AnakNya sendiri” (Kis 20:28). H. Senduk memberi arti tentang menggembalakan sebagai memimpin dan membina kepada pertumbuhan dan perkembangan. Di dalam penggembalaan, seorang gembala akan melakukan pekerjaanpekerjaannya, antara lain : menjaga, melindungi, memimpin, menyembuhkan, memberi makan dan mengasihi domba-domba yang telah dipercayakan oleh Kristus kepadanya (H.L Senduk, 2009, p. 40). 
Kewaspadaan dan selalu siap berjaga-jaga adalah ciri dari gembala yang baik. Charles Jefferson mengatakan bahwa waspada dan berjaga-jaga adalah hal yang penting dari semua tanggung jawab seorang gembala jemaat (Charles Jefferson, 1977, p. 43). Tugas gembala berikutnya adalah melindungi jemaat. Narasi Alkitab yang mengumpamakan jemaat seperti domba karena domba adalah binatang yang tidak dapat mempertahankan dirinya sendiri. Domba tidak diperlengkapi dengan senjata untuk menyerang atau membela dirinya dari musuh. Mereka tidak dapat menerkam, menggigit atau menerjang. Mereka dapat lari tetapi tidak secepat musuhnya. Domba gampang diserang, takut pada binatang-binatang lain, gampang dilukai, ditangkap, dirampas, disembelih dan dibunuh. Itulah sebabnya tugas gembala sidang adalah melindungi jemaat. Bila dikaitkan dengan pendapat Tage Sjoberg haruslah para pendeta berbuat cara yang sama seperti itu. Mereka harus melindungi domba-dombanya (jemaat) dengan berani dan tak gentar berperang melawan dosa, dunia, iblis dan berbagai pengajaran sesat yang dapat mengakibatkan kerugian dan kerusakan dalam kehidupan anggota jemaatnya (Sjoberg, 1997, p. 40).

Tugas seorang gembala sidang yang digambarkan oleh Injil Yohanes 10:4 mengandung makna bahwa seorang gembala adalah juga seorang pemimpin, sebab mengambil posisi berjalan dimuka dan domba-domba mengikutinya dari belakang. Christopher menyebut dalam Yohanes 10 ini setelah gembala membawa domba keluar dari kandang ke padang rumput, domba itu akan mengikutinya karena domba (jemaat) mengetahui dan "mengenali suara gembalanya. Oleh sebab itu, seorang gembala akan lebih rajin merawat dombanya dan menggunakan cara-cara tetap untuk memanggil mereka. Bentuk-bentuk isyarat domba ini akan dikenali oleh kawanan dan akan menandakan kehadiran gembala. Pada tingkat kiasan, yesus menggunakan ini sebagai gambaran tentang keakrabannya untuk menunjukkan kasih sayang kepada para pengikutnya (Skinner, 2018). John White mengatakan bahwa seorang pemimpin sejati melayani. Melayani orang-orang. Melayani demi mengusahakan yang terbaik bagi mereka, meskipun dengan berbuat demikian, pemimpin itu tidak akan selalu menjadi populer, tidak selalu membuat orang terkesan. Hal ini memberi petunjuk kepada gembala bahwa menjadi seorang pemimpin adalah seorang yang selalu berjalan dimuka dan memberi petunjuk-petunjuk bagi perkara-perkara tertentu yang harus dilaksanakan. Bahkan bukan hanya menjadi petunjuk saja, melainkan juga ikut memberi contoh dan cara bagaimana hal itu dilaksanakan (John White, 1994, p. 113).

Tugas yang lain lagi yang harus dilakukan oleh gembala sidang adalah bertanggung jawab atas kesehatan jiwa atau rohani jemaat, sebagaimana gembala harus memperhatikan domba-domba yang sakit. Sederhananya gembala bertugas menyembuhkan jemaat apabila ada yang sakit khususnya secara kerohanian. Peter Wongso mengemukakan yang terpenting ialah menyembuhkan penyakit rohani dengan firman Tuhan. Jadi Pendeta harus mengenal keadaan jemaatnya supaya dapat memberikan obat yang tepat, yaitu menanggung 'kelemahan dan penyakit' manusia (Mat. 8:17). Pada perkembangan akhir-akhir ini, pendeta bekerja sama dengan dokter. Dokter hanya menyembuhkan fisik seseorang sedangkan pendeta menyembuhkan penyakit yang sebenarnya, maka pendeta yang bekerja sama dengan dokter akan sukses. Tetapi pendeta dalam hal menyembuhkan harus bersandar pada kekuatan Roh Kudus dan doa. Dosa seringkali menjadi penyebab penyakit, hal ini baru dapat diselesaikan hanya melalui doa dan kekuatan Roh Kudus (Theologia Penggembalaan, 1996, p. 12).

Setelah seseorang diselamatkan maka ia memerlukan makanan untuk pertumbuhan rohani. Makanan itu adalah kebenaran firman Tuhan. Kewajiban seorang gembala adalah memberi makan kepada domba-domba dengan makanan firman Tuhan yang sehat dan bergizi (Frans Damazio, 1993, p. 73). Seorang pendeta adalah seorang gembala yang bertanggung jawab menyediakan makanan dan protein bagi domba-dombanya. Untuk menyediakan makanan itulah, dia harus menjadi pengajar Firman Allah (Hocking, 1994, p. 94). Hal ini disebabkan karena domba-domba tidak dapat mencari makanan dan minuman sendiri. Tugas gembala untuk membawa domba ketempat yang tersedia makanan. Gembala dari kawanan domba Allah adalah orang yang mengemban umat Allah dalam hatinya, memberi makan dengan roti kebenaran, melindungi mereka 
dari setiap masalah yang mungkin melemahkan imannya. Oleh Sendjaya mengemukakan pemimpin itu pemimpin yang menempatkan kebutuhan, aspirasi dan kepentingan orang lain di atas dirinya sendiri. Pilihan yang disengaja dari pemimpin pelayan adalah untuk melayani orang lain. Faktanya,pemimpin pelayan motif utama adalah untuk melayani lebih dulu, bukan memimpin (Sendjaya \& Sarros, 2002).

\section{Efisiensi Kepemimpinan Gembala Sidang}

Efisiensi asal kata efisien, artinya tepat atau sesuai untuk menghasilkan sesuatu dengan tidak membuang-buang waktu, tenaga dan biaya yang terlalu banyak. Efisiensi secara lengkap adalah ketepatan cara (usaha, kerja) dengan menggunakan tenaga, waktu dan uang sedikit tetapi menghasilkan (Henry Simamora, 1997, p. 32). Efisiensi berarti kemampuan menjalankan tugas dengan baik dan tepat dengan tidak membuang-buang waktu, tenaga dan biaya. Demikian halnya dalam kepemimpinan gembala, efisiensi gembala menyangkut pribadi gembala dapat dimaksimalkan potensi yang ada dalam dirinya.

Kepemimpinan serta manajemen penggembalaan menuju gereja yang bertumbuh, berdaya guna serta berhasil sepenuhnya terdapat pada gembala jemaat sebagai pemimpin. Jadi yang dimaksud dengan efisiensi kepemimpinan gembala yaitu gembala jemaat dengan ketepatan menggunakan sesuatu sekecil-kecilnya tetapi menghasilkan hasil sebesar-besarnya, meliputi waktu (Yakob Tomatala, 1997, p. 303). Waktu sangat berarti bagi setiap manusia apalagi bagi seorang gembala sebagai pemimpin. Pemimpin yang menghargai waktu sekecil apapun, maka dia akan selalu memanfaatkan waktu itu sebaik-baiknya. Sebagai contoh, gembala jemaat selalu tepat waktu atau sangat disiplin dimulainya ibadah atau selesainya ibadah. Ia juga selektif dalam menentukan waktu yang tepat dalam menentukan sesuatu bertalian dengan program-program gereja. Kemampuan penggunaan waktu yang diterapkan dengan bijaksana akan sangat menentukan keberhasilan dan sukses bagi gembala jemaat. Tanihardjo mengemukakan setiap pemimpin harus konsisten dalam perkataan maupun perbuatan, sesuai dengan kebenaran firman Tuhan yaitu doktrin-doktrin yang benar dalam Alkitab (Tanihardjo, n.d.).

Kemudian efisinsi kepemimpnan gembala terhadap jemaat juga berkaitan dengan tenaga (Tanihardjo, n.d., p. 308). Efisiensi tenaga di sini berarti bagaimana menggunakan tenaga yang ada secara efisien untuk melaksanakan setiap tugas guna mencapai hasil yang maksimal. Dengan kata lain, bagaimana menggunakan tenaga baik secara pribadi maupun tenaga yang tersedia untuk bekerja dan sukses. Dengan asumsi bahwa mutu diri sebagi gembala dan jemaat yang diberdayakan telah dipastikan potensi yang dimiliki, sehingga kini tinggal bagaimana menata dan mendayagunakan tenaga yang ada guna melaksanakan tugas yang ber-sasaran untuk mencapai hasil yang maksimal.

Efisinsi kepemimpinan gembala juga juga dilihat dana atau biaya (Tanihardjo, n.d., p. 307). Mengelola biaya secara efisien bukanlah pekerjaan yang mudah. Seorang gembala jemaat atau pemimpin gereja yang ahli memimpin dan efisien dalam penggunaan dana dapat menjamin efektivitas kepemimpinannya. Sekalipun banyak gereja menerapkan sistem keuangan gembala sebagai pemimpin menggunakan orang lain yang ahli dalam bidang keuangan, tetapi sebagai pemimpin, gembala selalu bertangung jawab untuk mengetahui dan mengelola serta menggunakan biaya dan sumber dana yang ada secara efisien apabila ia menginginkan keberhasilan dalam kepemimpinannya. Gembala sidang sebagai pemimpin harus memiliki kemampuan mengelola keuangan dengan prinsip-prinsip antara lain: mampu menetapkan serta memastikan anggaran berimbang bagi gereja untuk program jangka pendek maupun jangka panjang. Menerapkan sistem administrasi keuangan yang memudahkan pengontrolan disiplin penggunaan dana berdasarkan rasio berimbang yang telah ditetapkan. Hal ini perlu, supaya jangan terjadi "besar pasak dari pada tiang. Untuk menciptakan suasana poin di atas, maka perlu bekerja berdasarkan alokasi dana yang 
tersedia. Artinya dipastikan bahwa setiap pengeluaran dibuat berdasarkan anggaran. Menerapkan disiplin penggunakan dana yang tegas tetapi lugas.

Akdel Parhusip mengemukakan gereja memerlukan adanya manajemen dalam melakukan pelayanan, oleh karena itu manajemen gereja perlu dibuat oleh gereja, karena bila manajemen gereja tidak dibuat dengan baik dan tidak dilaksanakan dengan baik maka akan mengacaukan pelayanan yang dilakukan; hal ini tidak sesuai dengan kehendak Allah. Sebab, Allah tidak menghendaki kekacauan, tetapi damai sejahtera (I Kor. 14:33) (Parhusip, 2018). Craig pun menyatakan kesuksesan pendeta itu dipengaruhi kemampuannya dalam mengelola manajemen dan memimpin gereja. Karena itu pendeta menjalankan fungsinya dengan melayani spiritual jemaat, sekaligus ia mengolah manajemen gereja dan inilah yang disebut menjadi efektif, dan melaksakan perannya dengan baik (Irwin \& Roller, 2000). Langkah berikutnya yang dilakukan oleh seorang gembala untuk efisensi dalam kepemimpinannya adalah mengadakan evaluasi setiap pengeluaran dana untuk setiap program gereja. Menjadi pemimpin efektif haruslah ditunjang oleh segi efisiensi untuk membuktikan bahwa seseorang adalah pemimpin yang kompeten. Dengan demikian seorang gembala sebagai pemimpin efektif harus membuktikan keefektifannya dalam kinerja yang efisien.

Dengan efektifitas serta efisiensi tinggi yang dimiliki seorang pemimpin, maka ia dapat dianggap sebagai pemimpin yang komplit. Anggapan ini akan terbukti benar apabila efektivitas (mutu) kepemimpinan orang tersebut dapat diwujudkan dalam kinerja efisien (jumlah) yang tinggi dan produktif. Dengan gembala mengkolabarosikan ke-efektivitas dan ke-efisiensi dalam menggembalakan jemaat, akan menciptakan pertumbuhan gereja.

\section{Pertumbuhan Gereja}

Gereja ada demi dunia. Gereja menjadi transformator yang melahirkan ciptaan-ciptaan baru. Gereja menjadi tanda dan sarana Kerajaan Allah, bahkan gereja menjadi sakramen keselamatan bila di dalamnya tanda-tanda kerajaan Allah nampak dengan jelas: perdamaian, keadilan, kebenaran, dan kehidupan baru dalam cinta kasih (Widi Artanto, 1997, p. 60). Dari gereja yang missioner dan injili akan lahir gereja yang bertumbuh dan tersebar sebagai gereja-gereja lokal yang memancarkan kemuliaan Kristus. Gereja melahirkan gereja. Ini adalah suatu church planting yang bersifat program dan ideologis. Terjadi pertumbuhan baik dalam arti tunggal maupun jamak, sebagai goal dari aplikasi Amanat Agung. Donal McGavran menyatakan pertumbuhan gereja sebagai berarti segala sesuatu yang mencakup soal membawa orang yang tidak memiliki hubungan dengan Yesus Kristus ke persekutuan dengan Dia dan membawa mereka menjadi angota gereja yang bertanggung jawab (C. Peter Wagner, 2009, p. 46).

Pertumbuhan gereja adalah kehendak Allah, dari sudut pandang Alkitab, pertumbuhan gereja itu adalah tanda dari iman yang konsekuen. Seseorang dapat bertumbuh bila memiliki pengetahuan tentang Injil atau firman Allah. Alkitab menulis dalam (Ef. 4:13), faktor pertumbuhan itu tersirat sebagai karya dari Roh Kudus. Puncak dari petumbuhan itu adalah kedewasaan rohani umat Allah secara bersama-sama sebagai komunitas, sehingga sampai secitra dengan Kristus. Hal ini apabila dilihat dari aspek kualitas, tetapi bila dilihat dari aspek kuantitas, pertumbuhan gereja itu adalah pelipat-gandaan jumlah jiwa-jiwa.

Gembala jemaat harus memiliki bentuk pelayanan kedua pertumbuhan ini yang harus berjalan beriringan. Untuk pencapaian tujuan tentang pertumbuhan gereja, maka gembala jemaat perlu memahami strategi-strategi tertentu. Setiap kegiatan membutuhkan perencanaan dan teknik yang matang. Perlu metode pelaksanaan dengan sasaran yang jelas. Dibutuhkan langkah-langkah yang efektif dan efisien yang disebut strategi. Di dalam pertumbuhan gereja strategi mutlak dibutuhkan walaupun itu suatu hasil upaya pemikiran manusia, namun tidak berdosa bila dipakai dalam melaksanakan pekerjaan Allah. Strategi yang berkenan kepada Allah tentu akan diberkati, 
tetapi strategi yang duniawi yang tidak berkenan kepada-Nya, justru menghalangi keleluasan kerja Roh Kudus (C. Peter Wagner, 2009, p. 6).

Paul Cho Yonggi mengatakan gereja harus menanggapi adanya pertumbuhan gereja dengan serius, dengan menuntut perhatian penuh pada gereja Kristus pada masa -masa mendatang. Pertumbuhan gereja bukanlah hal kesukaan yang hanya sementara saja. Yesus datang untuk membangun gereja-Nya, dan gereja di masa kini cenderung stagnan pertumbuhannya. Sebab itu gereja perlu berupaya bagaimana supaya tidak terjadi stagnan (Paul Yonggi Cho, 1981, p. 101). Pertumbuhan gereja tidak dapat di hasilkan oleh manusia karena hanya Tuhan yang membuat gereja bertumbuh. Sebagaimana yang di jelaskan Paulus kepada jemaat di Korintus, "aku menanam, Apolos menyiram, tetapi Allah yang memberi pertumbuhan (I Kor.3:6). Paulus dan Apolos melaksanakan tugas mereka masing-masing, tetapi Allah yang menyebabkan pertumbuhan itu (Rick Warren, 1999, p. 18). Selanjutnya Stevens berpendapat bahwa pertumbuhan gereja sebagai kenaikan yang seimbang dalam kuantitas, kualitas serta kompleksitas organisasi sebuah gereja lokal (R. Janson \& Jim Stevens, 1996, p. 8). Dua aspek yang menandakan pertumbuhan gereja yang seringkali mendapat penekanan yang jelas, yaitu aspek kuantitas dan aspek kualitas. Dalam penekanannya berbeda-beda, ada yang hanya menjelaskan tentang pertumbuhan kuantitas dan ada yang lain menjelaskan pada sisi pertumbuhan kualitas. Namun sebenarnya pertumbuhan gereja lokal tidak terlepas dari kedua aspek tersebut.

Allah membentuk gereja demi dunia. Gereja menjadi agen, tempat dan lembaga untuk melahirkan ciptaan-ciptaan baru, yaitu petobat-petobat yang dipersatukan oleh kematian dan kebangkitan Kristus atau oleh Injil Kristus. Dari situ akan muncul generasi baru yang lahir oleh karya Kristus. Dengan bertumbuhnya gereja akan terjadi pertambahan jumlah anggota jemaat. Artinya gereja harus melahirkan gereja, sebagai bukti adanya church growth atau pertumbuhan gereja. Gereja merupakan alat bagi Allah untuk mendirikan jemaat-jemaat yang baru di seluruh dunia. Gereja yang bertumbuh adalah gereja yang berhasil melaksanakan misi pemberitaan injil Yesus Kristus. Adapun potensi yang paling ideal bagi pertumbuhan kuantitatif atau pertambahan bilangan jiwa-jiwa adalah pelayanan sekolah minggu. Pelayanan sekolah Minggu mempunyai bentuk tersendiri seperti yang di utarakan. Mimery ibadah anak-anak mempunyai ciri sendiri oleh karena semua hal yang menyangkut pelayanan harus anak, dan mengerti pula apa kebutuhannya serta latar belakangnya supaya proses belajar mengajar dapat di sesuaikan dengan kebutuhan anakanak itu, dengan tujuan membawa mereka bertumbuh (Nehemia Mimery, n.d., p. 70).

Pelayanan kepada Sekolah Minggu merupakan ladang yang sangat baik untuk pertambahan anggota jemaat. Semakin banyak jumlah kehadiran sekolah Minggu, maka semakin terbuka peluang tentang pertumbuhan gereja itu dalam sisi pertumbuhan kuantitatif. Kemungkinan besar, anak-anak pada masa sekarang ini akan menjadi anggota dewasa di masa mendatang. Oleh sebab itu mereka merupakan sumber yang melengkapi keanggotaan gereja kita (Ralp M. Riggs, 1996, p. 99). Sebagaimana sekolah Minggu merupakan ladang yang sangat potensial untuk penjangkauan jiwa-jiwa dengan tujuan pertumbuhan gereja secara kuantitatif, maka pemuda-remaja tidak kalah pentingnya dalam usaha perkembangan gereja. Gereja bertumbuh sebab di dalamnya memiliki tenaga-tenaga potensial karena pemuda remaja dapat diibaratkan punggung gereja. Seperti yang dikatakan oleh Ralph M. Riggs, bahwa kaum muda lebih penuh semangat dari pada orang yang lebih dewasa, sebab itu memerlukan waktu-waktu tambahan untuk pengungkapan daya semangat. Oleh karena itu pemuda-remaja hendaknya diberdayakan dalam pelayanan. Jika mereka tidak diberi kesempatan untuk melayani, maka mereka akan mengikuti gaya hidup mereka sendiri. Pertumbuhan gereja terlihat dari apakah ada semangat atau tidak di lingkup pemuda-remaja local itu (Ralp M. Riggs, 1996, p. 103).

Pertumbuhan jemaat secara kuantitatif juga tidak lepas dari bertambahnya jumlah anggota dewasa atau bapa dan ibu dalam setiap ibadah. Menurut sejarah pertumbuhan gereja mula-mula terdapat di Yerusalem, bila dilihat dari aspek kuantitatif. Seperti apa yang di tulis oleh Lukas dalam 
kitab Kisah Para Rasul. Di sana di temukan bahwa anggota jemaat mula-mula berjumlah seratus dua puluh orang (Kis. 1:5). Namun jumlah tersebut bertambah menjadi tiga ribu orang pada hari Pentakosta (Kis. 2:41-42), kemudian angka tersebut bertambah lagi menjadi lima ribu orang dalam beberapa hari (Kis. 4:4). Pertumbuhan jemaat mula-mula begitu cepat bila melihat dari laporan Lukas dalam kitab (Kis. 21:20), di mana Lukas menggunakan istilah "murid" yang menunjuk kepada jumlah sepuluh ribu. Apabila membaca laporan Lukas dalam (Kis. 9:31), pertumbuhan jemaat bukan hanya terdapat di Yerusalem saja, tetapi juga sudah sampai ke Yudea, Galilea, dan Samaria dan diberbagai daerah (Kis. 16:5). Carson dan Douglas mengemukakan bahwa kitab yang ditulis Lukas tersebut penuh dengan banyak peristiwa yang menandai lahirnya gereja mula-mula, bagaimana pertambahan jumlah orang percaya, manifestasi berbagai mukjizat yang semuanya itu bagian dari perbuatan Roh Kudus melalui pelayanan para Rasul di dalam menaati perintah memberitakan Injil dimulai dari Yerusalem, kemudian Yudea dan Samaria, hingga ke ujung bumi (D.A Carson and Douglas J. Moo, 2016, p. 323).

Roy Pointer mengatakan bahwa gereja masa kini pertumbuhan secara kuantitatif terjadi berdasarkan empat segi pertumbuhan, meliputi pertumbuhan biologis, pertumbuhan perpindahan, pertumbuhan restorasi dan yang terakhir adalah pertumbuhan konversi (Roy Pointer, 1989, p. 29). Yang dimaksud dengan pertumbuhan biologis adalah anak-anak dan remaja dari anggota aktif yang datang dan terdaftar sebagai anggota gereja. Sedangkan perpindahan adalah perekrutan anggotaanggota yang siap menjalani kehidupan Kristen melalui transfer dari jemaat lain dikarenakan kerja, studi dan lain sebagainya. Kemudian yang dimaksud dengan pertumbuhan restorasi adalah pemulihan dari orang-orang yang dulunya telah mundur dari Tuhan dan kembali menjadi anggota aktif dalam pelayanan. Pertumbuhan pertobatan adalah orang-orang bukan Kristen yang telah menerima dan menjadi murid Kristus dengan kata lain mereka adalah orang-orang yang memiliki latar belakang non-kristen namun telah mengambil keputusan untuk menerima Yesus sebagai Tuhan dan Juruselamat dalam hidupnya dan menjadi anak Allah.

Pertumbuhan secara kualitatif dimaknai adanya buah-buah iman dalam kehidupan orang percaya. Seperti apa yang dikatakan oleh Watuseke pertumbuhan Gereja secara kualitatif meliputi orang yang baru percaya bertumbuh menjadi suka berdoa, tekun mempelajari firman Allah, suka berkorban (memberi), tekun dalam persekutuan, suka bersekutu dalam kasih (H.Watuseke, n.d., p. 32). Adapun ciri-ciri dari pertumbuhan kualitatif antara lain jemaat tekun dalam firman Allah. Seperti halnya gereja mula-mula mereka tekun dalam pengajaran rasul-rasul (Kis 2:42). Mereka bertekun di dalam pemberitaan firman yang disampaikan oleh para rasul-rasul. Pertumbuhan jemaat secara kualitas nampak dari kesetiaan mereka kepada Injil. Dengan demikian mereka mampu untuk mengaplikasikan firman itu dalam kehidupan sehari-hari. Tekun dan hidup di dalam pengajaran firman Tuhan adalah salah satu kekuatan utama di dalam kehidupan rohani jemaat mula-mula. Mereka menaklukan diri dan mengikuti secara konsisten semua hal baru yang diajarkan para rasul di Yerusalem. Kelompok ini berakar di dalam firman karena mereka mau dididik dan diajar dengan kebenaran (Zaluchu, 2019).

Pertumbuhan gereja secara kualitatif itu juga meliputi jemaat tekun berdoa. Setiap anggota jemaat tekun dalam doa (KPR 2:42), mereka menempatkan doa sebagai bagian yang tidak terpisahkan dalam hidup mereka. Karena dari doa mereka dapat membangun hubungan yang intim dengan Allah dalam kehidupan mereka sehari-hari. Jemaat yang bertumbuh secara kualitatif pasti mereka aktif dalam doa baik secara pribadi maupun doa dalam persekutuan bersama. Ciri yang ketiga dari pertumbuhan gereja secara kualitatif adalah jemaat suka memberi. Setiap anggota jemaat tekun dalam hal memberi (Kis 2:45). Mereka bertekun dalam pelayanan diakonia kepada sesama anggota. Sebagai penerapan pada jemaat masa sekarang ini adalah mereka memiliki jiwa rela berkorban demi pekerjaan Allah, sehingga gereja dapat maju dan berkembang karena tersedia dana. Kesetiaan jemaat dalam memberi perpuluhan adalah suatu bukti bahwa jemaat setia melakukan firman Allah. Jemaat yang bertumbuh secara kualitatif taat dan setia melakukannya sesuai firman Allah dalam (Mal. 3:10). Menurut Whitney, perilaku suka menolong dan menjadi 
bagian dari kebutuhan orang lain tersebut, adalah ciri dari orang yang lahir baru di dalam Kristus. Perhatian kepada sesama dan kebutuhan sesamanya menjadi menjadi salah satucara untuk merefle ksikan diri mereka sebagai pengikut Yesus (Donald S. Whitney, 2011, p. 80).

Ciri berikutnya dari pertumbuhan gereja secara kualitatif adalah jemaat saling mengasihi satu dengan yang lain. Kehidupan jemaat tercipta saling mengasihi terhadap sesama bukan hanya oleh mandat dari rasul, melainkan oleh dorongan kasih sebagai bukti dari watak yang telah diubahkan (Kis. 2:45). Jemaat dapat bersatu oleh karena saling mengasihi di antara satu dengan yang lain. Setiap jemaat yang telah lahir baru dan bertumbuh secara kualitas, dia harus mampu menerapkan kehidupan yang saling mengasihi dan saling membantu dalam mengatasi setiap masalah yang dihadapi. Pentakosta awal tidak hanya menjadikan orang-orang yang berkumpul di Yerusalem menjadi makhluk rohani, yang hanya berurusan dengan persoalan rohani,melainkan juga memiliki tanggung jawab atau kepedulian sosial. Mereka yang memiliki lebih tidak egois dengan milik mereka, melainkan berusaha untuk berbagi demi keberlangsungan hidup Bersama (Siahaan, 2017). Gereja yang bertumbuh adalah gereja yang kuat serta kokoh dalam iman. Mereka memiliki anggota jemaat yang berkualitas. Di sinilah gembala jemaat sebagai pemimpin gereja dengan segala kemampuan yang dimiliki seharusnya dapat menjadi benteng dalam memberikan dan mengarahkan ajaran yang benar.

\section{Kesimpulan}

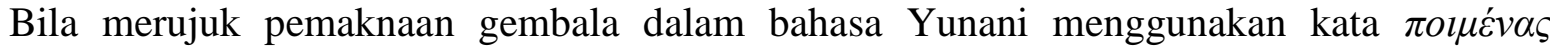
(poimenas) yang diartikan sebagai seorang pemberi makan, pelindung dan penuntun. Makna dari gembala sidang itu sampai sekarang masih relevan dengan didefiniskan sebagai yang memimpin hidup jemaat dan menata kehidupan rohani untuk semakin bertumbuh pada kedewasaan di dalam Tuhan. Tuhan menetapkan seseorang menjadi gembala karena ia mempunyai tugas dan tanggung jawab agar kehidupan spiritual rohani jemaat terjaga dan pertumbuhan gereja terjadi melalui kepemimpinan gembala itu. Besarnya tugas dan tanggung jawab di pundak gembala mendorong dia untuk efisien dalam memimpin jemaat agar tercapai pertumbuhan gereja. Ke-efisien itu dimulai dari terampil memberdayakan manajemen penggembalaan, efisien dalam penggunaan waktu dan materi menyangkut urusan ke-pelayanan. Dengan efisiensi kepemimpinan gembala dalam menggembalakan jemaat, itu menciptakan gereja bertumbuh secara kuantitas dan bertanggungjawab terhadap pelayanan. 


\section{REFERENCE}

Borrong, R. P. (2015). Signifikansi kode etik pendeta. Gema Teologi, 39(1).

C. Peter Wagner. (2009). Gereja Saudara Dapat Bertumbuh. Gandum Mas.

Charles Jefferson. (1977). Pejabat Gereja Sebagai Gembala Sidang. Mimery Press.

Cohall, K. G., \& Cooper, B. S. (2010). Educating American Baptist pastors: A national survey of church leaders. Journal of Research on Christian Education, 19(1), 27-55.

Crider, S. M. and D. (2002). Gembala Sidang Dan Pelayanannya. Kalam Hidup.

D.A Carson and Douglas J. Moo. (2016). D.A Carson and Douglas J. Moo, An Introduction to the New Testament. Gandum Mas.

Dedy Mulyana. (2002). No Metode Penelitian. Rosdakarya.

Donald S. Whitney. (2011). Spiritual Check Up - 10 Pertanyaan Untuk Memeriksa Kesehatan Rohani Anda. Yayasan Gloria.

Frans Damazio. (1993). Kunci-kunci Efektif Bagi Kepemimpinan Yang Sukses. Harvest Publication House.

H.L Senduk. (2009). Ekonomi Allah Dalam GerejaNya. Bethel.

H.Watuseke. (n.d.). SDM dan Pertumbuhan Gereja(Jakarta : Dep.Lit\&M.M. GPdI,"tt”)32. Dep. Lit \& M .M. GPdI.

Handi Irawan \& Bambang Budijanto. (2020). Kunci Pertumbuhan Gereja Berdasarkan Temuan Survei Nasional BRC. YAYASAN BILANGAN RESEARCH CENTER.

Henry C Thiessen. (2010). Teologi Sistimatika (Vernon D Doerksen (Ed.); 8th ed.). Gandum Mas.

Henry Simamora. (1997). Manajemen SDM. STIE YKPN.

Hocking, D. (1994). Rahasia Keberhasilan Seorang Pemimpin. Andi Offset.

Irwin, C. E., \& Roller, R. H. (2000). Pastoral preparation for church management. Journal of Ministry Marketing $\backslash \&$ Management, 6(1), 53-67.

John White. (1994). Kepemimpinan Yang Handal. Kalam Hidup.

Kosta, Y., \& Djadi, J. (2011). Peranan Gembala Sebagai Pemimpin Dalam Perspektif I Petrus 5: 14 Dan Relevansinya Pada Masa Kini. Jurnal Jaffray, 9(2), 172-200.

Nehemia Mimery. (n.d.). Rahasia Tentang Penggembalaan Jemaat. Mimery Press.

Parhusip, A. (2018). PERAN MANAJEMEN TERHADAP PERKEMBANGAN PELAYANAN DI GEREJA. DIDACHE-Jurnal Pendidikan Dan Teologi Pentakosta, 1(1).

Paul Yonggi Cho. (1981). Kelompok Sel Yang Berhasil. Gandum Mas. 
R. Janson \& Jim Stevens. (1996). Dinamika Pertumbuhan Gereja. Gandum Mas.

Ralp M. Riggs. (1996). Gembala Sidang Yang Berhasil. Gandum Mas.

Rick Warren. (1999). Pertumbuhan Gereja Masa Kini. Gandum Mas.

Roy Pointer. (1989). How to Church Grow. British Church Growt Assoceation.

Sendjaya, S., \& Sarros, J. C. (2002). Servant leadership: Its origin, development, and application in organizations. Journal of Leadership $\backslash \&$ Organizational Studies, 9(2), 57-64.

Siahaan, H. E. R. (2017). Karakteristik Pentakostalisme Menurut Kisah Para Rasul. DUNAMIS: Jurnal Teologi Dan Pendidikan Kristiani, 2(1), 12-28.

Simon, S. (2019). Fenomena Sosial Climber Ditinjau Dari Perspektif Etika Kristen. Fidei: Jurnal Teologi Sistematika Dan Praktika, 2(2), 303-324.

Simon Simon. (2020). Peran Roh Kudus Bagi Hamba Tuhan Dalam Merintis Gereja. LOGIA: Jurnal Teologi Pentakosta, 1(2).

Sjoberg, T. (1997). Sidang Jemaat Allah Yang Berfungsi. Mimery Press.

Skinner, C. W. (2018). “ The Good Shepherd Lays Down His Life for the Sheep”(John 10: 11, 15, 17): Questioning the Limits of a Johannine Metaphor. The Catholic Biblical Quarterly, 80(1), 97-113.

Tanihardjo, B. (n.d.). Integritas Seorang Gembala Sidang dan Keberhasilan Pelayanan di Gereja Lokal. KS.

Theologia Penggembalaan. (1996). SEMINARI ASIA TENGGARA.

Widi Artanto. (1997). Menjadi Gereja Misioner Dalam Konteks Indonesia. Kanisius.

Yakob Tomatala. (1997). Kepemimpinan yang Dinamis. Gandum Mas.

Zaluchu, S. E. (2019). Eksegesis Kisah Para Rasul 2: 42-47 Untuk Merumuskan Ciri Kehidupan Rohani Jemaat Mula-Mula Di Yerusalem. EPIGRAPHE: Jurnal Teologi Dan Pelayanan Kristiani, 2(2), 72-82.

Zed, M. (2008). Metode Penlitian Kepustakaan. Yayasan Obor Indonesia. 